\title{
PERIPHERAL ARTERIAL DISEASE AND CHRONIC KIDNEY DISEASE
}

Marijan Bosevski

University Cardiology Clinic, University of Ss. Cyril and Methodius, Skopje, Republic of Macedonia

Corresponding author: Marijan Bosevski, University Cardiology Clinic, University of Ss. Cyril and Methodius, Skopje, Republic of Macedonia, email: marijanbosevski@yahoo.com

\section{ABSTRACT}

There are two points of interplay of chronic kidney (CKD) and peripheral arterial disease (PAD): $\mathrm{CKD}$ has been recognized as one of the main factors for presence of $\mathrm{PAD}$, and PAD has been defined as a useful tool for risk stratification of CKD population.

Peripheral arterial disease in patients with CKD is a frequent finding, even in those without symptoms.

This review tends to describe determinants for occurrence of arterial disease in chronic kidney disease patients and necessity for its screening.

Key words: peripheral arterial disease, chronic kidney disease, screening, risk factors, prognosis

\section{INTRODUCTION}

Cardiovascular disease (CVD) has been found in many studies as a high prevalent in patients with chronic kidney disease (CKD). Despite many studies dealing with coronary artery disease in CKD, there aren't too many indicating the intersection of the peripheral arterial disease (PAD) and CKD.

Coexistent PAD and renal artery disease are not uncommon. PAD as part of the CVD is found in $26-32 \%$ of the patients with CKD. The results from the National Health and Nutrition Examination Survey (NHANES) survey of PAD indicate that $24 \%$ of the persons with creatinine clearance $<60 \mathrm{~mL} / \mathrm{min} / 1.73 \mathrm{~m} 2$ have PAD compared with $3.7 \%$ of the persons with creatinine clearance $>60$ $\mathrm{mL} / \mathrm{min} / 1.73 \mathrm{~m} 2$ [1]. ARIC studies and Heart and Estrogen/Progestin Replacement Study (HERS) revealed $C K D$ as an independent risk factor for PAD with hazard ratio $1.1-3$. Over $50 \%$ with end stage renal disease (ESRD) have some kind of vascular disease. The presence of PAD could additionally worsen the renal function in CKD patients $[2,3]$.
CKD is linked with more extensive vascular disease than in the general population. There is a poor survival in those patients when both diseases are presented. The explanation is due to the mortality based on the coronary and cerebrovascular events in the patients with PAD (Figure 1) [4]. Additional facts are the high prevalence of the non-traumatic limb amputations in $\mathrm{CKD}$, which is twice to three times higher than in the general population [5].

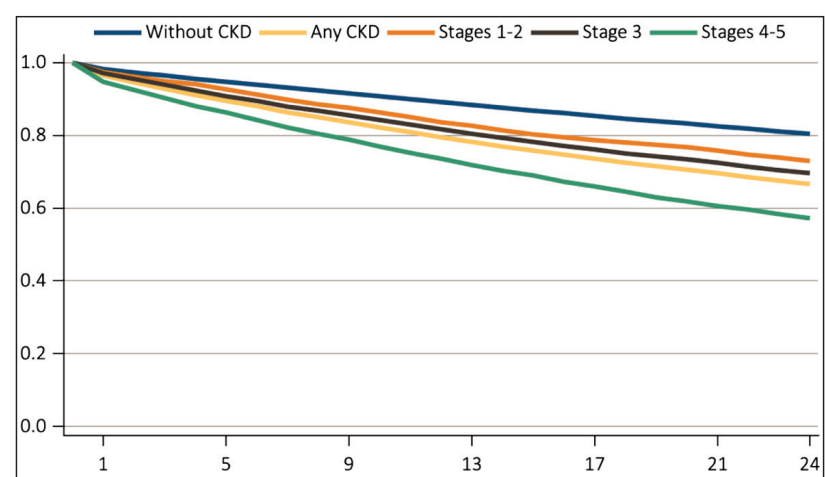

Figure 1. Survival of PAD patients with presented CKD 


\section{RISK FACTORS}

Patients with PAD and CVD share the same traditional risk factors: age, diabetes, hypertension, hyperlipidemia, and smoking. However, the presence of PAD in CKD is associated with some unique risk factors, as: albuminuria reduced GFR, inflammation, oxidative stress, endothelial dysfunction and abnormal metabolism of calcium and phosphate [6].

Table 1. Risk factors for PAD and CVD i general population and CKD

\begin{tabular}{|l|l|}
\hline Traditional & Non traditional \\
\hline Age & Albuminuria \\
\hline Diabetes & Reduced GFR \\
\hline Hypertension & Inflammation \\
\hline Hyperlipidemia & Oxidative stress \\
\hline Smoking & Endothelial dysfunction \\
\hline Physical inactivity / Obesity & Anemia / malnutrition \\
\hline
\end{tabular}

4D trial showed that patients with hyperlipidemia including with CKD have cumulative hazard from cardiac events twice to three times more if the target lipid levels are not reached. Diabetes and Hypertension are risk factors for all-cause death with the presence of heart failure in patients with CKD. Global Kidney Forum highlights the prevention of cardiovascular risk factors in CKD pts [7]. Every recommendation includes therapy goals for blood pressure treatment, lipid and glycemic control. The systematic review of randomized trials revealed that patients with CKD or diabetes and hypertension benefit much more with target blood pressure goal $<130 / 80 \mathrm{mmHg}$ than $<140 / 80 \mathrm{mmHG}$. LDL should be the primary target for lipid control with value of $1.8 \mathrm{mmol}$ (or $50 \%$ reduction from the initial value in very high risk patients), and $2.6 \mathrm{mmol} / \mathrm{l}$ in high risk patients. According to the ESC Guidelines 2016 every CKD with GFR $30-59 \mathrm{ml} / \mathrm{min} / 1.73 \mathrm{~m}^{2}$ or PAD is a high risk patient. Very high risk patient is the one with GFR $<30 \mathrm{ml} / \mathrm{min} / 173 \mathrm{~m}^{2}$ or CKD with history or documentation of PAD or coronary artery disease [8].

These unique risk factors are involved in the depicted mechanisms of vascular calcification in chronic kidney disease, as a particular atherosclerotic process in these patients [9]. This is the reason some authors revealed CKD as a risk factor for vascular disease.

It has been recognized that phosphate had vascular toxicity and role in formation of vascular calcification [10]. Impaired endothelial function is an early phase of atherosclerotic disease and could be used for stratification of risk of vascular disease pts [11].

On the other hand, albuminuria in the general population, together with traditional risk factors predicts the risk of cardiovascular morbidity and all-cause mortality. Some authorities propose GFR to be added to the Framingham risk score because of independent role in cardiovascular prognosis in CKD and population with risk factors $[12,13]$.

Our data revealed that inflammation in addition to other risk factors is in relation to carotid intima media thickness in this population, and in cardiovascular mortality, as well $[14,15]$. European and American guidelines recommend testing of CKD patients for detection of anemia and feritin level as risk factors for heart failure and cardiovascular mortality [16].

\section{SCREENING FOR PERIPHERAL ARTERIAL DISEASE}

Most of the published data support detection of PAD in CKD pts. A recent study showed that low $A B I$ is predictor of organ failure, secondary end points and death [17]. This study made on 819 patients show prevalence of $46 \%$ of $\mathrm{PAB}$ in CKD. DOOPS and the Chronic Renal Insufficiency Cohort (CRIC) Studies' results show necessities for screening of PAD because of high prevalence found in CKD population [18]. Own study done in the Department of Nephrology Skopje with collaboration of Cardiology showed frequent presence of PAD (over 50\%) when done on population with CKD on hemodyalis. This study also shows high prevalence of carotid plaques $(88 \%)$ in patients with low $\mathrm{ABI}$ and support screening for PAD in CKD [19].

The US Preventive Services Task Force recommendations on screening for PAD do not recommend it. Most of the societies and guidelines give recommendations for screening of PAD (Table 2) [20-22].

European Society for cardiology recommend vascular imaging in high risk patients (CKD included) as a risk modifier with class IIA or B [8]. The American Societies used PAD as a useful tool for risk stratification of CKD pts The cardiovascular risk scores (FRS-CVD and ASCVD [AHA/ ACC 2013]) can estimate the probability of atherosclerotic cardiovascular events in patients with CKD regardless theri renal function.

Some of the explanations why PAD is so important are that it is an advanced atherosclerotic 
Table 2. Recommendations for Detection of PAD in Clinical Practice

\begin{tabular}{|l|}
\hline KDOQI \\
\hline - At the time of dialysis therapy initiation, all patients should be evaluated for the presence of PAD \\
- Evaluation should include physical examination, including assessment of arterial pulse \\
abnormalities are detected upon physical examination and if interventions are considered \\
\hline TASC II \\
\hline Recommend screening for PAD in: \\
- Patients with exertional leg symptoms \\
- Patients aged $50-69$ y with cardiovascular risk factors \\
- All patients aged $\geq 70$ y \\
- Pts with a 10 -y risk of a cardiovascular event of $10-20 \%$, determined by SCORE / Framingham \\
\hline ACC/AHA \\
\hline Recommend screening for PAD in: \\
- Patients aged $<50$ y with diabetes and additional CVD risk factor \\
- Patients $\geq 50$ y with any CVD risk factor (smoking, diabetes, hypertension, elevated cholesterol) \\
\hline
\end{tabular}

Legend. KDOQI = National Kidney Foundation TASC=Inter-Society Consensus of Treatment of PAD,

ACC $=$ American College of Cardiology, AHA=American Heart Association

disease with cumulative effect from many risk factors. Because PAD is a systemic manifestation of atherosclerosis it defines high risk patients per se.

Due to our experience we also recommend for PADs screening in CKD pts, also. Early detection may improve patient and clinician awareness of the potential significance of future leg symptoms or signs of more advanced PAD. This could lead to more intensive risk-factor intervention or initiation of medical therapies to improve limb symptoms and overall cardiovascular morbidity.

The most simple and used tool is the Ankle-Brachial Index (ABI). Its relation to traditional risk factors and renal function in high risk patients, was presented previosly [23]. It is sensitive and accurate tool that provides diagnostic information with value $\leq 0.90$, or $>1,3$. Contrast-based angiographic tests: computed tomography and magnetic resonance angiography are important tools in PAD diagnosis. However, advanced CKD patients have the highest risk of iodinated contrast-induced nephrotoxicity. That's why they could be replaced with non-invasive imaging ultrasound techniques (echo color Doppler) in CKD population.

\section{CONCLUSION}

PAD is underdiagnosed and undertreated disease defined as a risk factor for $\mathrm{CKD}$ patients. $\mathrm{CKD}$ has been recognized as one of the main factors for prognosis of $\mathrm{PAD}$, and $\mathrm{PAD}$ has been defined as a useful tool for risk stratification of CKD population.
The strategy for screening for PAD in CKD patients should be realized by multidisciplinary approach of nephrologists and cardiologist, in the way to improve clinical outcomes of this population.

\section{REFERENCES}

1. O'Hare AM, Glidden DV, Fox CS, Hsu CY. High prevalence of peripheral arterial disease in persons with renal insufficiency: results from the National Health and Nutrition Examination Survey 1999-2000. Circulation 2004; 109:320.

2. O'Hare AM, Vittinghoff E, Hsia J, Shlipak MG. Renal insufficiency and the risk of lower extremity peripheral arterial disease: results from the Heart and Estrogen/Progestin Replacement Study (HERS). J Am Soc Nephrol 2004; 15:1046.

3. Wattanakit K, Folsom AR, Selvin E, et al. Kidney function and risk of peripheral arterial disease: results from the Atherosclerosis Risk in Communities (ARIC) Study. J Am Soc Nephrol 2007; 18:629.

4. Foley RN, Murray AM, Li S, et al. Chronic kidney disease and the risk for cardiovascular disease, renal replacement, and death in the United States Medicare population, 1998 to 1999. J Am Soc Nephrol. 2005;16(2):489-495.

5. Eggers PW, Godhes D, Pugh J. Nontraumatic extremity amputations in the Medicare end- 
stage renal disease population. Kidney Int. 1999;56 (4):1524-33

6. Menon V. Gul A, Sarnak MJ. Cardiovascular risk factors in chronic kidney disease. Kidney Int. 2005;68(4):1413-8.

7. Levin A, Tonelli M, Bonventre J, Coresh J, Donner JA, Fogo AB, Fox CS, Gansevoort RT, Heerspink HJL, Jardine M, Kasiske B, Köttgen A, Kretzler M, Levey AS, Luyckx VA, Mehta R, Moe O, Obrador G, Pannu N, Parikh CR, Perkovic V, Pollock C, Stenvinkel P, Tuttle KR, Wheeler DC, Eckardt KU; ISN Global Kidney Health Summit participants. Global kidney health 2017 and beyond: a roadmap for closing gaps in care, research, and policy. Lancet. 2017 Apr 20. pii: S0140-6736(17)30788-2. doi: 10.1016/S0140-6736(17)30788-2.

8. Authors/Task Force Members:, Catapano AL, Graham I, De Backer G, Wiklund O, Chapman MJ, Drexel H, Hoes AW, Jennings CS, Landmesser U,Pedersen TR, Reiner Z, Riccardi G, Taskinen MR, Tokgozoglu L, Verschuren WM, Vlachopoulos C, Wood DA, Zamorano JL. 2016 ESC/EAS Guidelines for the Management of Dyslipidaemias: The Task Force for the Management of Dyslipidaemias of the European Society of Cardiology (ESC) and European Atherosclerosis Society (EAS) Developed with the special contribution of the European Assocciation for Cardiovascular Prevention \& Rehabilitation (EACPR). Atherosclerosis. 2016;253:281-344.

9. Schiffrin EL, Lipman ML, Mann JF. Chronic kidney disease: effects on the cardiovascular system. Circulation. 2007 Jul 3;116(1):85-97.

10. Gross P, Six I, Kamel S, Massy ZA. Vascular toxicity of phosphate in chronic kidney disease: beyond vascular calcification . Circ J. 2014;78(10):2339-46.

11. Bosevski M, Borozanov V, Tosev S, Georgievska-Ismail $\mathrm{Lj}$. Is assessment of eripheral endothelial dysfunction useful tool for risk stratification of type 2 diabetic patients with manifested coronary artery disease? Int J Cardiol. 2009 Jan 9;131(2):290-2.

12. Smink PA, Lambers Heerspink HJ, Gansevoort RT, de Jong PE, Hillege HL, Bakker SJ, de Zeeuw D. Albuminuria, estimated GFR, traditional risk factors, and incident cardiovascular disease: the PREVEND (Prevention of Renal and Vascular Endstage Disease) study. Am J Kidney Dis. 2012 Nov;60(5):804-11
13. Chang A, Kramer H. Should eGFR and albuminuria be added to the Framingham risk score? Chronic kidney diseaseand cardiovascular disease risk prediction. Nephron Clin Pract. 2011;119(2):c171-7;

14. Dzekova Vidimliski P, Ivanovski N, Bosevski M, Busletic I, Sikole A. Association betwwn Hepatitis C and Carotid IMT in renal transplant recipient. Int journal of artificial organs 32(7):443-443

15. Selim G, Stojceva-Taneva O, Zafirovska K, Sikole A, Gelev S, Dzekova P, Stefanovski K, Koloska V, Polenakovic M. Inflammation predicts all-cause and cardiovascular mortality in haemodialysis patients. Prilozi. 2006 Jul;27(1):133-44.

16. Silveberg D. Cardio-renal anemia iron deficiency syndrome (CRAID). Proceeding of $3^{\text {rd }}$ Cardionephrology Congress 2017;116-120

17. Patel SI, Chakkera HA, Wennberg PW, Liedl DA, Alrabadi F, Cha SS, Hooley DD, Amer H, Wadei HM, Shamoun FE. Peripheral arterial disease preoperatively may predict graft failure and mortality in kidneytransplant recipients. Vasc Med. 2017;22(3):225-230.

18. Rajagopalan S, Dellegrottaglie S, Furniss AL,. Peripheral arterial disease in patients with end-stage renal disease: Observations from the Dialysis Outcomes and Practice Patterns Study (DOPPS). Circulation 2006; 114: 1914-1922

19. Gelev S, Spasovski G, BosevskiM, Tosev S, Sikole A. Different Ankle Brachial Index Levels in Asymptomatic Hemodialysis Patients. Bantao J 2006;4(2):41-6

20. National Kidney Foundation. K/DOQI Clinical Practice Guidelines for Cardiovascular Disease in Dialysis Patients. Am J Kidney Dis. 2005;45(4)(suppl 3):S1-S153.

21. Norgren L, Hiatt WR, Dormandy JA, et al. Inter-Society Consensus for the Management of Peripheral Arterial Disease (TASC II). Eur J Vasc Endovasc Surg. 2007;33(Suppl 1):S1-S75.

22. Hirsch AT, Haskal ZJ, Hertzer NR, et al. ACC/ AHA 2005 practice guidelines for the management of patients with peripheral arterial disease (lower extremity, renal, mesenteric, and abdominal aortic): a collaborative report from the American Association for Vascular Surgery/Society for Vascular Surgery, Society for Cardiovascular Angiography and Interventions, Society for Vascular Medicine and 
Biology, Society of Interventional Radiology, and the ACC/AHA Task Force on Practice Guidelines: endorsed by the American Association of Cardiovascular and Pulmonary Rehabilitation; National Heart, Lung, and Blood Institute; Society for Vascular Nursing; TransAtlantic Inter-Society Consensus;
andVascular Disease Foundation. Circulation. 2006;113(11):e463-e654.

23. Bosevski M, Soedamah-Muthu SS. Blood urea level and diabetes duration are independently associated with ankle-brachial index in type 2 diabetic patients. Diabetes Metab Syndr. 2012;6(1):32-5.

\section{ПЕРИФЕРНА АРТЕРИСКА БОЛЕСТ И ХРОНИЧНА БУБРЕЖНА БОЛЕСТ}

Маријан Бошевски

\section{Резиме}

Постојат две точки на сооднос на хроничната бубрежна (ХББ) и периферната артериска болест (ПАБ): ХББ е признат како еден од главните фактори за присуство на ПАБ, а ПАД е дефинирана како корисна алатка за ризик стратификација на популацијата со ХББ.

Периферната артериска болест кај пациенти со ХББ е чест наод, дури и кај оние кои се асимптоматски.

Овој преглед има тенденција да ги опише факторите за појава на периферната артериска болест кај пациенти со хронична бубрежна болест и потребата од нејзин скрининг.

Клучни зборови: периферна артериска болест, хронична бубрежна болест, скрининг, фактори на ризик, прогноза 